удк 339.138

\title{
МАРКЕТИНГОВІ ДОСЛІДЖЕННЯ ФАКТОРІВ УСПІШНОСТІ ПРОВЕДЕННЯ PR-ЗАХОДІВ
}

\author{
MARKETING RESEARCH \\ OF PR-ACTIVITIES SUCCESS' FACTORS
}

\author{
Федорова Тетяна Олександрівна \\ здобувач, \\ Одеський національний економічний університет \\ ORCID: https://orcid.org/0000-0003-0949-0459
}

\author{
Fedorova Tatyana \\ Odessa Nationals Economics University
}

\begin{abstract}
Стаття присвячена результатам маркетингового дослідження фракторів успішності проведення PR-заходів в різних умовах - до і після впровадження локдауну у зв'язку з пандемією COVID-19 на фрармацевтичному ринку південного регіону України. Автор порівняв споживацькі вподобання, особливості прийняття рішення про участь в PR-заходах в онлайн та офрлайн форматах. У якості важливих факторів для обрання конкретного PR-заходу цільовою аудиторією запропоновано фрактори коморорту, зручність отримання інфрормації, співвідношення інформаційної та розважальної складових у змісті програми заходу, вплив особистості лектора та зацікавленість в конкретній темі PR-заходу. Через запропоновану систему оцінки еоективності в нових соціально-економічних умовах ізоляції сформовано принципи розробки маркетингових заходів в цифровому середовищі для підприємств, що діють на основі нових бізнес-моделей.
\end{abstract}

Ключові слова: цифрова економіка, інтернет-маркетинг, маркетингові дослідження, маркетингова фрункція підприємства.

Статья посвящена результатам маркетингового исследования фракторов успешности проведения PRмероприятий в различных условиях - до и после внедрения локдауна в связи с пандемией COVID-19 на фрармацевтическом рынке южного региона Украины. Автор сравнил потребительские предпочтения, особенности принятия решения об участии в PR-мероприятиях в онлайн и офлайн форматах. B качестве важных фракторов для выбора конкретного PR-мероприятия целевой аудиторией предложены фракторы комфорта, удобство получения информации, соотношение инорормационной и развлекательной составляющих в содержании программы мероприятия, влияние личности лектора и заинтересованность в конкретной теме PR-мероприятия. Через предложенную систему оценки эффективности в новых социально-экономических условиях изоляции сорормированы принципы разработки маркетинговых мероприятий в цифровой среде для предприятий, действующих на основе новых бизнес-моделей.

Ключевые слова: цифровая экономика, интернет-маркетинг, маркетинговые исследования, маркетинговая фрункция предприятия.

The article is devoted to the results of marketing research of PR-events success factors in different conditions before and after the introduction of lockdown in connection with the pandemic COVID-19 in the pharmaceutical market of the southern region of Ukraine. The survey was conducted among 168 doctors in 2 stages: in December 2019 and in August 2020. The author compared consumer preferences, features of decision-making on participation in PR-events in online and offline formats. As important factors for choosing a specific PR-event, the target audience offers comfort factors, ease of obtaining information, the ratio of information and entertainment components in the content of the event program, the influence of the lecturer's personality and interest in a specific topic of the PRevent. Through the proposed system of evaluation of efficiency in the new socio-economic conditions of isolation, the principles of development of marketing measures in the digital environment for enterprises operating on the basis of new business models are formed. Identified success factors deconstruct the process of communication in both online and offline activity of the enterprise to understand the optimal combination of these elements in further use in practice of marketing activities. It is important to note that there has been a rapid digitalization among the target audience. According to the results of marketing research, it was found that further implementation and use of digital channels of marketing communications will develop in the pharmaceutical and other industries, due to the possibility 
of disseminating professional information and acquiring new competencies by visitors to such PR events. The rapid formation of leaders in this market is noted, which can significantly deconstructs the traditional methods of communication and the movement of values that were formed before the pandemic. Internet marketing communication is becoming a significant tool of marketing policy of the enterprise and requires further attention and study.

Keywords: digital economy, internet marketing, marketing research, marketing function of the enterprise.

Постановка проблеми. Деконструкція ціннісних ланцюгів під впливом нових технологій та зміни у поведінки споживачів призводить до необхідності адаптувати маркетингову фрункцію підприємства під існуючі умови. Поява підприємств, побудованих за новими бізнес-моделями, які надають посередницькі послуги у цифровому просторі, обумовлюють дослідження фракторів, що впливають на ефрективність маркетингових заходів в цілому.

Аналіз останніх досліджень і публікацій. Підприємства знаходяться в постійних умовах пошуку нових конкурентоспроможних маркетингових рішень, тому автором досліджено проблематику щодо бізнес-моделей та їхнього використання на ринку В2В за останні 15 років. Деякі автори займаються більше теоретичними основами існування БМ: Дж. Магретта [1], М. Льюіс [2]. Інші приділяють увагу прикладним характеристикам бізнес-моделювання, а саме, О. Остервальдер та І. Піньє [3], Г. Чезборо [4], Дж. Паркер, М. Альстін, С. Чаударі [5; 6]. Зміни маркетингменеджменту в новому тисячолітті відмічає Ф. Котлер [7]. Автор А. Соолятте [8], приділяє увагу еволюції та класифрікації бізнес-моделей. Дослідження впливу IT на роботу компаній, особливо на ринках В2В, можна знайти в роботах М. Леві [9], І. Л. Литовченко та інших авторів [10, с. 86; 12; 13], які досліджують зв'язок між бізнес-моделями та стратегією.

Виділення невирішених раніше частин загальної проблеми. Впровадження новітніх інформаційних Інтернет-технологій у маркетингові комунікації та принципи, за якими потрібно будувати ефрективні кампанії, ще потребують подальшого вивчення. В умовах цисррової економіки підприємства повинні постійно шукати нові способи підвищення своєї конкурентоспроможності. Впровадження PR-кампаній комунікацій у складі маркетингового комплексу підприємства зараз $€$ актуальною задачею маркетолога.

Постановка завдання. Завдання статті дослідження потенціалу впровадження нових маркетингових активностей та фракторів формування вподобань цільової аудиторії (надалі - ЦА) на прикладі PR-кампаній в Інтернет через запропоновану систему оцінки їх ефективності в нових соціально-еконо- мічних умовах ізоляції та локдауну завдяки пандемії з метою формування принципів розробки маркетингових заходів в цифрровому середовищі на основі нових бізнес-моделей.

Виклад основного матеріалу дослідження. На сьогоднішній день виникає необхідність вивчення фракторів, що деконструюють процес комунікації як в онлайн-, так і в офрлайн-просторі активності підприємства для розуміння оптимального поєднання цих елементів у подальшому використанні в маркетингової діяльності на практиці.

Нами було проведено маркетингове дослідження ЦА фрармацевтичної компанії на ринку південного регіону України. Для цього було розроблено анкету оцінки чинників, що впливають на рівень задоволення від проведення PR-заходів відвідувачами навчальних спеціалізованих закладів постдипломної освіти. Опитування відбувалося серед 168 лікарів в Одеській області, у тому числі в м. Одеса. 3 метою виявлення ставлення аудиторії до різних фрорматів PR-заходів, як в онлайн так і в офлайні. Дослідження проводилось в 2 етапи (періоди). Перший етап було реалізовано у грудні 2019 року серед 95 респондентів до початку локдауну, а другий - у серпні 2020 року серед 72 респондентів вже після першої хвилі пандемії.

За умови того, що лікарі вузьких спеціальностей (кардіологи, неврологи та інші) мають тенденцію частіше отримувати інформацію 3 онлайн джерел, ніж лікарі загальної практиці, в вибірку намагались включити усі спеціальності лікарів у рівній мірі. Таким чином, розподілення за цим критерієм в обох періодах було дуже схоже, тому будемо вважати, що опитування проводилось на тій самій цільовій аудиторії (рис. 1).

В анкеті було запропоновано оцінити декілька фракторів за шкалою від 1 до 10, де 1 та 10 - крайні прояви одного питання:

- Фактори комфорту, що можуть впливати на рішення зацікавленої аудиторії відвідувати PR-заходи. Серед них нами було виділено окремо місце проведення заходу: якщо нове та незнайоме - 1 бал, дуже знайоме - 10 балів; також підприємство-організатор заходу: якщо невідоме - 1 бал, дуже відоме - 10 балів.

- Зручні канали отримання інформації та ступень користування цифровими джере- 


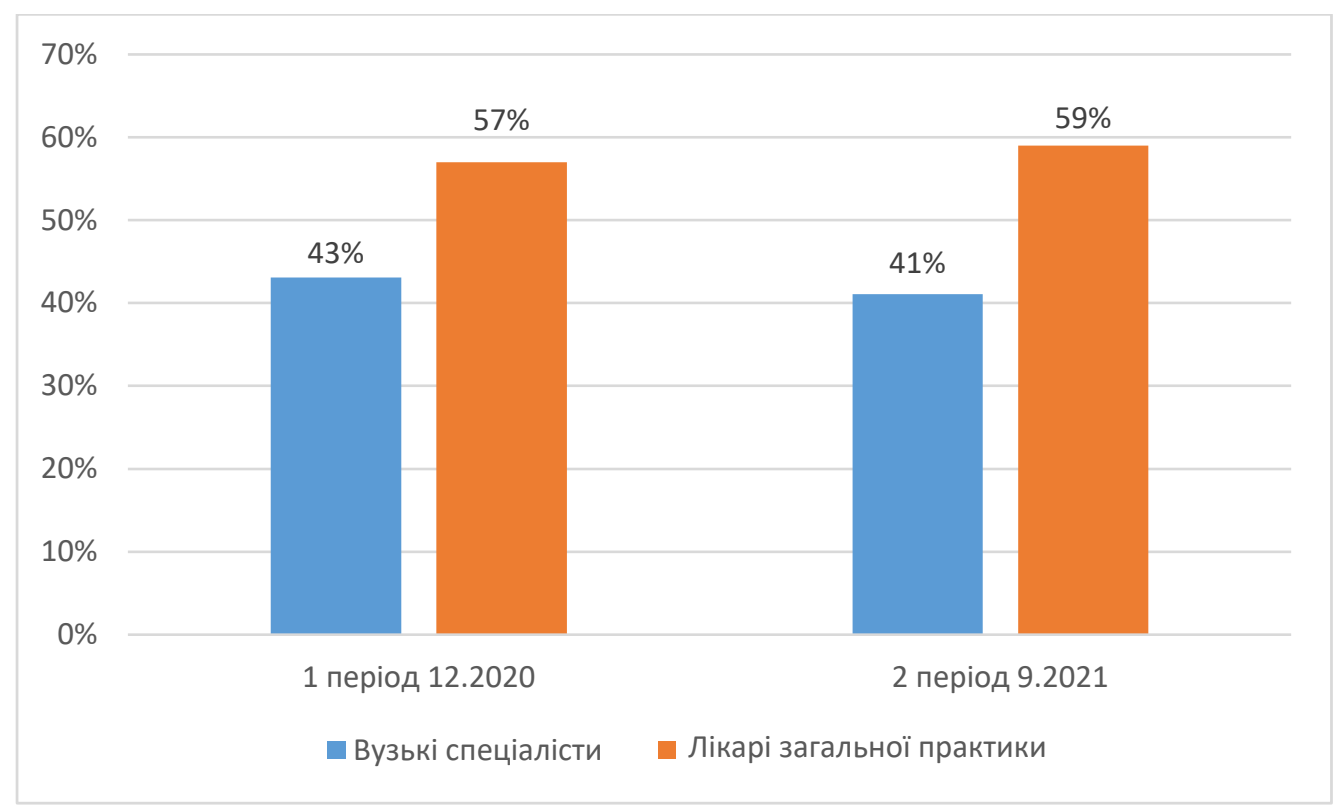

Рис. 1. Розподілення респондентів за спеціальностями у 2-х періодах маркетингового дослідження

Джерело: за матеріалами автора

лами інсормації серед цільової аудиторії. Було важливо встановити кількість контактів, які можна взагалі встановити з цільовою аудиторією за допомогою цифрових каналів комунікації. Якщо респондент зовсім не отримує інфрормацію онлайн, а тільки офрлайн - 1 бал, якщо отримує інсрормацію тільки з цисррових джерел/носіїв - 10 балів.

- Програма PR-заходу часто крім інорормаційної складової приваблює відвідувачів ще й розважальними елементами, тому дуже важливо виявити що саме впливає на рішення про відвідування. Тому в анкеті обов'язково присутнє питання щодо цілі відвідування заходу. Якщо респондент відповідав, що його метою $є$ тільки добре провести час, то 1 бал, а якщо виключно отримати інформацію - то 10 балів.

- Якість запропонованого PR-заходу часто залежить від експертності та популярності лектора, що висвітлює головну тему зустрічі, тому цілком логічне питання про мотивацію в участі в заході такого формату: якщо респондент відповідає, що його більш приваблює лектор - отримуємо 1 бал, якщо він взяв участь через тему заходу - 10 балів. В майбутньому це дає можливість спланувати залучення цільової аудиторії.

Були отриманні наступні результати (рис. 2).

За період 3 грудня 2019 до пандемії до серпня 2020 після першої хвилі пандемії та лоқдауну значно змінився спосіб отримання інорормації у ЦА. Якщо до початку пандемії середній бал за відвідуванням PR-заходів у цифровому форматі та пошуком інформації в Інтернет був оцінений на 3 бали, що можна вважати за дуже низький, то вже у серпні 2020 він піднявся до 8,33 балів - майже максимальний.

Важливо зазначити, що відбулася стрімка цифрровізація серед ЦА. У перший період дослідження частка респондентів, які зовсім не використовували циоррові джерела для комунікації та отримання профресійної інфоормації було 52 серед 95 опитуваних, що складає 53\%. У другому періоді не було жодного респондента, який би відмітив, що не користується цисровими джерелами. Такий показник проникнення цифррових комунікаційних засобів дозволяє охопити більшу частку ЦА, з якою ще 9 місяців до цього неможливо було формувати контакт.

В анкеті були ще декілька пунктів, які дозволяли висловлювати свою думку респондентам в вільній фрормі без шкали оцінки. Зазначено, що в перший період в грудні 2019 на питання: «На яких сайтах Ви зараз отримуєте інфрормацію?», більшість респондентів не могли дати відповідь, або записували соцмережі - такі як Facebook без уточнення. У другий період в серпні 2020 було отримано багато більш детальної інфрормації з вказанням спеціалізованих сайтів, назв груп y Facebook, Youtube каналів, платфрорм посередників, таких як «Бібрайт» або «Гіпократ» 
Досвід участі у заході в он-лайн форматі. 1 - немає, 10 - отримаю інформацію тольки в он-лайн форматі.

Місце проведення заходу нове - 1, знайоме -10.

Відвідують захід для розваги - 1 бал, або для отримання інформації

Приваблює більше постать лектора - 1 бал, тема доповіді - 10 балів

Підприємство-організатор заходу невідоме 1, відоме - 10

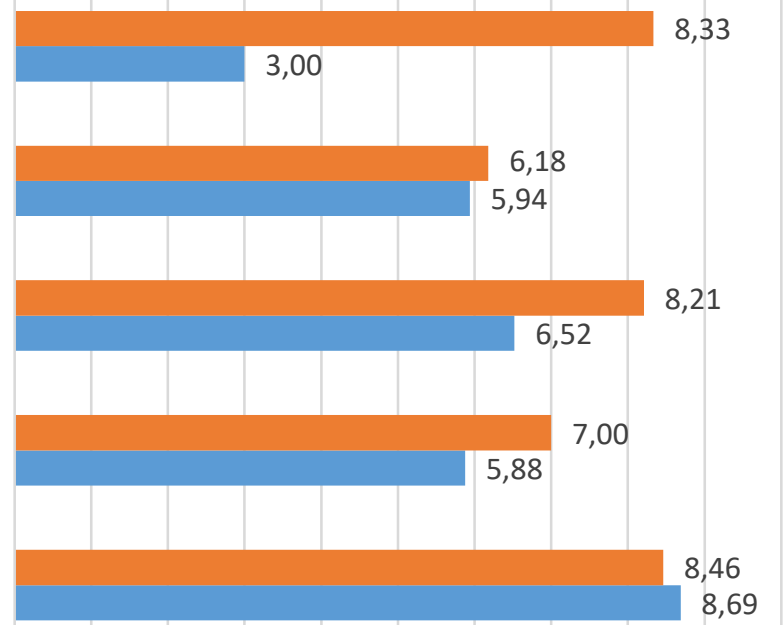

$\begin{array}{lllllllllllll}0,00 & 1,00 & 2,00 & 3,00 & 4,00 & 5,00 & 6,00 & 7,00 & 8,00 & 9,00 & 10,00\end{array}$

— 2 період $9.2020 \quad$ — 1 період 12.2019
Рис. 2. Динаміка зміни вподобань ЦА PR-заходів у 2-х періодах маркетингового дослідження

Джерело: за матеріалами автора на яких були викладені трансляції доповідей. Всі ці фракти підтверджують думку, що інтернет-маркетингова комунікація за останній рік стає значним інструментом маркетингової політики підприємства та потребує подальшої уваги та вивчення.

Два показники, які майже не змінилися впродовж 2019/2020 рр. - це місце проведення заходу (нове чи знайоме) та підприємство-організатор (відомий чи ні). Респонденти однаково прихильні як до нових локацій, так і до знайомих. А також більш віддають перевагу запрошенням від більш відомих підприємств. Очевидно, що це пов'язано з репутацією організатора, який сорормував довіру у респондентів комфрортом та інфрормаційною наповненістю заходу.

Залучення ЦА - один із ключових фракторів успіху будь-якої комунікаційної кампанії. У цифрровому середовищі багато переваг, крім можливості організації розважальної частини PR-заходу, що зазвичай в онлайні забезпечити важче. Тому фрактор залучення ЦА залишається в зоні розвитку для подальшого планування та організації онлайн заходів. Із-за цього результати опитування респондентів до лоқдауну та у період пандемії значно відрізняються. Значно більше опитуваних серпні 2020 більш були схильні відвідувати трансляції завдяки цікавій темі доповіді, ніж завдяки особистості лектора. У той час, як раніше особливих уподобань не було. Показник змінився з 5,77 балів у грудні 2019 до 7 балів у бік теми доповіді у серпні 2020.

Також спостерігається зміщення результатів опитування у показнику «цілі відвідування»: з розважальної - добре провести час, до інфрормаційної - отримати необхідну інфрормацію. Це лише підтверджує припущення щодо необхідності розвитку та просування розважальної або інтерактивної частини онлайн заходу. Так як в подальшому, при насиченні ринку інформаційними заходами, залучення ЦА в онлайн-просторі може падати. У грудні 2019 респонденти в середньому відмітили тільки 6,52 бали з незначною перевагою у бік отримання інформації, тобто значною мірою в очікуваннях від заходу або особистого контакту 3 представниками фрармацевтичної компанії були і розважальні цілі. У серпні 2020 цей показник виріс до 8,21 балів. Тобто респонденти чекали нової інфрормації та вважали, що буде зручно отримувати її в онлайн режимі. Якщо ця тенденція задоволеності в отриманій інформації буде зберігатися й далі, то зацікавленість у відвідуванні онлайн PR-заходів та отримання інорормації в цисрровому вигляді може падати.

Висновки. За результатами маркетингового дослідження було виявлено, що 
подальше впровадження й використання цифрових каналів маркетингових комунікацій буде розвиватися в фрармацевтичній та інших галузях, завдяки можливості поширення профресійної інфрормації та набуття нових компетенцій відвідувачами таких PR-заходів.

По-перше, підприємствам потрібно приділяти більш уваги поширенню маркетингової комунікацій онлайн та вивчати поведінку ЦА в Інтернеті, тому що фрактори, які забезпечували конкурентну перевагу офлайн можуть мати меншу вагу онлайн, або зовсім втрачати свою цінність.
По-друге, з'являються нові компанії, що побудовані не за лінійним, а за цифровим принципом платсрормного типу, які можуть надавати посередницькі послуги. Вони допомагають зв'язувати різні ЦА та отримувати доступ до споживачів, які раніше були для них важко доступні. Використовуючи рекламу в соціальних мережах або інших цисррових методів залучення, вони отримують нових споживачів та фрормують охват. Зазначено швидке формування лідерів в цьому ринку, що значною мірою може деконструювати традиційні методи комунікації та рух цінностей, що були сорормовані до пандемії.

\section{СПИСОК ВИКОРИСТАНИХ ДЖЕРЕЛ:}

1. Why business models matter? URL: https://hbr.org/2002/05/why-business-models-matter

2. Льюис М. Новейшая новинка. История Силиконовой долины / Пер. с англ. Москва : ОлимпБизнес, 2004. 384 с.

3. Остервальдер А., Пинье И. Построение бизнес-моделей : настольная книга стратега и новатора / Пер. с англ. 8-е изд. Москва : Альпина Паблишер, 2017. 288 с.

4. Чезборо Г. Открытые бизнес-модели / Пер. с англ. Москва : Поколение, IP-менеджмент, 2008. 254 с.

5. Альстин М., Паркер Дж., Сангит П. Ч. Сетевой эффект как новый двигатель экономики. Сборник статей как развивать бизнес в эпоху изменений // Harvard Business Review, № 2, Poссия, 2017. С. 27-31.

6. Паркер Дж., Альстин М., Чаудари С. Революция платформ / Пер. с англ. Москва : МИФ, 2017. 321 с.

7. Котлер Ф. Маркетинг-менеджмент в новом тысячелетии / Пер. с англ. Санкт-Петербург : Питер, 2002. 750 c.

8. Сооляттэ А. Бизнес-модели компаний: определение, эволюция, классификация. URL: http://www.klubok.net/ article2302.html

9. Леви М. Гениальность на заказ. Легкий способ поиска нестандартных решений и идей / Пер. с англ. Москва : Манн, Иванов, Фарбер; Эксмо, 2010. 123 с.

10. Литовченко И. Л. Генезис и эволюция инфрормационной концепции маркетинга : монография. Киев : Наукова думка, 2011. 200 с.

11. Федорова Т. А. Основы управления проектами на базе маркетинговой бизнес-модели 3.0. Науковий вісник Херсонського державного університету. 2015. № 13. Ч. 4. С. 91-96.

12. Литовченко І. Л. Маркетингові дослідження ринку В2В в Інтернет-середовищі. Вісник соціально-економічних досліджень. Одеса : ОДЕУ, 2011. Вип. 41. Ч. 2. С. 76-83.

13. Федорова Т. А. Сучасні бізнес-моделі компаній-посередників на ринку В2В. Вісник соціально-економічних досліджень. Одеса : ОДЕУ, 2018. Вип. 4(68). С. 193-202.

\section{REFERENCES:}

1. Why business models matter? Available at: https://hbr.org/2002/05/why-business-models-matter

2. Lewis, M. (2004). Newest novelty. History of Silicon Valley. Trans. from Eng. [Noveyshaya novinka. Istoriya Silikonovoy doliny; per. s angl.]. Moscow: Olimp-Biznes, 384 p. (in Russian)

3. Osterwalder, A., Pigneur, Y. (2017). Business model generation: a handbook for visionaries, game changers, and challengers. Trans. from Eng. 8th ed. [Postroenie biznes-modeley: nastolnaya kniga stratega i novatora; per. s angl.]. Moscow: Alpina Pablisher, 288 p. (in Russian)

4. Chesbrough, H. (2008). Open business models. Trans. from Eng. [Otkrytye biznes-modeli; per. s angl.]. Moscow: Pokolenie, IP-menedzhment, 254 p. (in Russian)

5. Alstyne, M., Parker, G., Sangeet, P. Ch. (2017). Network effect as a new engine of economy. Collection of articles on how business develop in a change era [Setevoy effekt kak novyy dvigatel ekonomiki. Sbornik statey kak razvivat biznes v epokhu izmeneniy]. Harvard Business Review, no. 2, Rossiya, pp. 27-31. (in Russian)

6. Parker, G., Alstyne, M., Choudary, S. (2017). Platform revolution: how networked markets are transforming the economy - and how to make them work for you. Trans. from Eng. [Revolyutsiya platform; per. $s$ angl.]. Moscow: MIF, 321 p. (in Russian)

7. Kotler, Ph. (2002). Marketing management: Millennium edition. 10th ed. [Marketing-menedzhment v novom tysyacheletii; per. s angl.]. Sankt-Peterburg: Piter, 750 p. (in Russian) 
8. Soolyatte, A. Business models of companies: definition, evolution, classification [Biznes-modeli kompaniy: opredelenie, evolyutsiya, klassifikatsiya]. Available at: http://www.klubok.net/article2302.html (in Russian)

9. Levi, M. (2010). The genius to order. Easy way to find the creative solutions and ideas. Trans. from Eng. [Genialnost na zakaz. Legkiy sposob poiska nestandartnykh resheniy i idey; per. s angl.]. Moscow: Mann, Ivanov, Farber; Eksmo, 123 p. (in Russian)

10. Lytovchenko, I. L. (2011). Genesis and evolution of information marketing concept: monograph [Genezis i evolyutsiya informatsionnoy kontseptsii marketinga: monografiya]. Kyiv: Naukova dumka, 200 p.

11. Fedorova, T. A. (2015). Fundamentals of project management based on the marketing business model 3.0 [Osnovy upravleniya proektami na baze marketingovoy biznes-modeli 3.0]. Naukovyi visnyk Hersonskoho derzhavnoho universytetu, no. 13, ch. 4, pp. 91-96.

12. Lytovchenko, I. L. (2011). Market researches of B2B market in Internet environment [Marketynhovi doslidzhennia rynku B2B v Internet-seredovyshchi]. Socio-economic research bulletin. Odessa: Odessa National Economic University, no. 41(2), pp. 76-83. (in Ukrainian)

13. Fedorova, T. (2018). Modern business-models for intermediary companies on B2B market. Ed.: M. Zveryakov (ed.-in-ch.) and others [Suchasni biznes-modeli kompanii-poserednykiv na rynku B2B; za red.: M. I. Zvieriakova (gol. red.) ta in.]. Socio-economic research bulletin. Odessa: Odessa National Economic University, no. 4(68), pp. 193-202. 